\title{
Pengelolaan Kelas Terhadap Siswa Tuna Rungu-Wicara di Kelompok A1 PGRA Mamba'ul Hisan
}

\author{
Aprilia Rahmawati ${ }^{1}$, Juhaeni ${ }^{2}$, Siti Aisah ${ }^{3}$, Ayu Kinasih $^{4}$, Nur Shibyany ${ }^{5}$
}

Received: 1912 2019/ Accepted: 2112 2019/ Published online: 28122019

(C) 2019 Early Chilhood Islamic Education Study Program

\begin{abstract}
Children with special needs including children who are deaf-speech are children who have the right to get teaching and develop according to their potential. Like normal children in general, children who are deaf-mute have problems that must be resolved so that they can perform maximally. One of them is by providing education. Education is very important in life to eradicate ignorance. Teachers and parents must also be seen in the teaching process of students. . This study aims to describe the classroom management by teachers of children with deaf-speech cases. This research uses a qualitative research approach with qualitative descriptive research methods. Data collected by interview techniques, observation of the learning process and documentation.The result, class management must also be in accordance with the conditions of students so that students are interested and can follow the learning well and in accordance with what is expected.
\end{abstract}

Keyword : deaf-Speech are, class management

\begin{abstract}
Abstrak : Anak-anak berkebutuhan khusus termasuk didalam nya anak tuna rungu-wicara adalah anak yang mempunyai hak untuk mendapatkan pengajaran dan berkembang sesuai potensi yang mereka miliki. Seperti halnya anak-anak normal pada umumnya, anak tuna rungu-wicara memiliki masalah yang harus diselesaikan agar mereka dapat berprestasi secara maksimal. Salah satunya dengan memberikan pendidikan. Pendidikan sangat penting dalam kehidupan untuk mengurangi kebodohan. Guru dan orang tua harus terlibat dalam proses pengajaran siswa. Penelitian ini bertujuan untuk mendeskripsikan pengelolaan kelas yang dilakukan guru terhadap anak dengan kasus tunarungu-wicara. Penelitian ini menggunakan pendekatan penelitian kualitatif dengan metode penelitian deskriptif kualitatif. Data dikumpulkan dengan teknik wawancara, observasi terhadap proses pembelajaran dan dokumentasi. Hasil penelitian merekomendasikan bahwa pengelolaan kelas mesti sesuai dengan kondisi siswa supaya tertarik dan bisa mengikuti pembelajaran dengan baik dan sesuai dengan apa yang diharapkan.
\end{abstract}

Kata kunci : tuna rungu-wicara, pengelolaan kelas

\footnotetext{
${ }^{1}$ UIN Sunan Ampel Surabaya

${ }^{2}$ UIN Sunan Ampel Surabaya

${ }^{3}$ RA Mam'baul Hisan Surabaya

${ }^{4}$ UIN Sunan Ampel Surabaya

${ }^{5}$ UIN Sunan Ampel Surabaya
} 


\section{PENDAHULUAN}

Anak tuna rungu-wicara adalah anak-anak yang memiliki berbagai macam permasalahan dikarenakan ketidak mampunya dalam berkomunikasi dengan lingkungan, dimana dia tumbuh dan berkembnag. Ketidak mampuannya dalam berkomunikasi tersebut merupakan permasalahan yang dimiliki oleh anak yang memiliki keterbatasan dalam tuna rungu-wicara. Salah satu pemicu anak-anak tuna rungu-wicara yakni mudah putus asa dalam hal ketidak mampuan mereka dalam bersosialisasi terhadap masyarakat dan lingkunagn sekitar. Salah satu cara yang bisa dilakukan yaitu dengan cara memberikan pendidikan yang menarik dan nyaman bagi anak.

Di sekolah PGRA Mambaul Hisan terdapat salah satu murid yang menderita cacat tuna rungu-wicara, tepatnya dikelompok A1. Anak tersebut menderita tuna runguwicara sejak lahir, sehingga anak tersebut memiliki hambatan saat berkomunikasi. Anak tersebut berasal dri keluarga yang berpendidikan. Ibunya sangat peduli terhadap pendidikan anaknya dan setiap berangkat ke sekolah selalu diantar oleh ibunya. Pada saat di sekolahan anak tersebut memakai alat bantu dengar untuk memudahkan dia saat berkomunikasi. Anak tersebut mudah bergaul saat di sekolah. Anak tersebut bisa mengikuti pembelajaran dengan baik, perkembangannya tumbuh pesat yaitu perkembangan kognitif, fisik motorik, bhasa, moral, seni, dan sosial emosialnya sudah berkembang sesuai dengan apa yang diharapkan, meskipun ada beberapa hal yang kurang maksimal.

Guru kelasnya sangat memperhatikan tumbuh kembang dari anak tersebut, mulai dari aktifitasnya dikelas maupun dirumah. Guru kelas menggunakan strategi pendekatan dalam pengelolaan kelas. Selalu menggunakan metode tepukan jika ingin berbicara dengan siswa anak berkebutuhan khusus tersebut. Guru kelas selalu belajar tentang bagaimana cara berkomunikasi dengan siswa tersebut tanpa membedakan dengan yang lain. Hal ini juga merupakan tantangan bagi guru pengelola kelas.

Penelitian ini bertujuan untuk meneliti pengelolaan kelas yang mana kelas tersebut terdapat siswa tuna rungu-wicara. Siswa tersebut membuat kita tertarik untuk kita jadikan objek penelitian, karena hanya dengan visual siswa tersebut bisa menyelesaikan tugasnya dengan baik bahkan siswa yang normal pun kemampaunnya ada yang dibawah anak berkebutuhan khusus tersebut

\section{METODE}

Penelitian ini metode penelitianya yang digunakan adalah metode penelitian deskriptif kualitatif yakni melakukan pengumpulan data, menganalisis data kemudian mendeskripsikan data secara kualitatif berdasarkan data yang terkumpul. Pengumpulan data penelitian dilakukan dengan metode wawancara dan observasi. Observasi ini merupakan observasi partisipan. Peneliti melakukan observasi dari dalam kelas terhadap kegiatan belajar dan untuk melengkapi data, peneliti melakukan wawancara terhadap guru kelas selaku guru yang mengajar dan mengelola kelas dan orang tua siswa yang menyandang tuna rungu-wicara untuk mengetahui bagaimana perkembangan anak ketika di rumah, sekolah dan lingkungan sekitar. Dokumentasi juga dilakukan dalam penelitian ini untuk melengkapi data tentang kemajuan perkembangan anak dengan tuna rungu-wicara. Analisis dalam penelitian ini dilakukan dengan langkah pertama adalah reduksi data. Reduksi data dilakukan untuk memilih dan memilah data yang diperoleh 
berupa kata, kalimat maupun peristiwa yang diamati dalam pembelajaran. Kedua adalah memaparkan data yang diperoleh terkait dengan pembelajaran untuk anak tuna runguwicara di kelas oleh guru dan juga perlakuan orangtua di rumah. Langkah ketiga dalam analisis penelitian adalah melakukan verivikasi. Penulis dalam hal ini menyimpulkan hasil analisis tentang pembelajaran untuk anak dengan kasus tuna rungu-wicara.

\section{HASIL PENELITIAN DAN ANALISIS}

Penelitian ini, analisis data diawali dari hasil wawancara. Hasil wawancara dengan orang tua partisipan, peneliti mendapatkan hasil bahwa anaknya yang bernama Musa Ratungga yang mana mempunyai kelebihan khusus yaitu tuna rungu-wicara sebenarnya lahir dalam keadaan normal. Hanya saja telinga Musa mengalami masalah kurang dengar, sehingga membuat dia juga sulit untuk berbicara. Orang tua Musa sangat peduli terhadap pendidikan Musa. Musa disekolahkan di PGRA Mamba'ul Hisan dengan alasan guru yang ada di sana sangat telaten meskipun sekolahan tersebut bisa dikatakan belum mampu menerima anak berkebutuhan khusus. Tetapi dengan tekad yang bulat, sekolah tersebut akhirnya menerima Musa sebagai siswa di PGRA Mamba'ul Hisan. Orang tua Musa tidak menuntut sekolah untuk keberhasilan Musa dalam akademik tapi lebih ke sosialnya Musa.

Selain sekolah di PGRA Mamba'ul Hisan, Musa juga menjalani terapi wicara di Malang setiap hari Sabtu dan terapi pendengaran di RSAL setiap hari Senin. Terapi tersebut guna melatih pendengaran Musa dan melatih Musa supaya bisa berbicara. Semenjak satu tahun Musa menjalani terapi, Musa sudah mulai terlihat perkembangannya. Yang awalnya Musa bicara hanya menunjuk sesuatu sekarang Musa sudah bisa memanggil mama, ayah, dan kata yang biasa diucapkan sehari-hari.

Menurut Bu Isa guru kelasnya, Musa sangat cerdas. Dia seumuran dengan temantemannya yang lain. Kemampuannya juga tidak kalah dengan teman-temannya yang lain. Dia tidak bisa mendengar, tapi hanya denga visual saja dia mampu memahami tugas yang diberikan oleh guru. dan dia mampu menyelesaikan tugasnya dengan baik dan itu tidak dimiliki mereka yang normal. Terkadang mereka yang normal, mengerjakan tugas ada yang belum paham tapi Musa tidak. Dia mampu melakukan tugasnya hanya dengan melihat. Perkembangannya sangat luar biasa.

Ketunarunguan dibedakan menjadi dua kategori yaitu tuli (deaf) dan kurang dengar (hard of hearing). Tuli adalah mereka yang indra pendengarannya mengalami kerusakan dalam taraf berat sehingga pendengaran tidak berfunngsi lagi. Sedangkan kurang dengar adalah mereka yang indra pendengarannya mengalami kerusakan tetapi masih dapat berfungsi untuk mendengar, baik dengan maupun tanpa menggunakan alat bantu dengar, Somantri (2006: 93). Ketunarunguan yang dialami oleh seorang anak akan menyebabkan konsekuensi yang kompleks bagi anak, terutama perkembangan anak menjadi sangat terhambat. Effendi (2006:55) menyataka bahwa diakibatkan gangguan pendengaran yang dialami, anak akan mengalami berbagai hambatan dalam meniti perkembangannya, terutama pada aspek bahasa, kecerdasan dan penyesuaian sosial.

Sadjaah dan Sukarja (1995:116) Hallahan dan Kaufman mengemukakan, ketidakmampuan berbahsa/bicara disebabkan oleh tiga faktor yang saling berkaitan yaitu: 
1. Penerimaan bunyi memalui pendengaran tidak cukup sebagai umpan balik untuk menyuarakan bunyi. Sebagai akibat gangguan pendengaran, maka bunyi yang didengarnya tidak sempurna.

2. Penerimaan bahasa/bicara dari orang yang sengaja mengajak bicara, tidak cukup untuk menunjang pendengarannya.

3. Anak tunarungu tidak mampu mendengar contoh bahasa/bicara dari orang yang mengajak bicara. Oleh karena perbendaharaan kata kurang, anak tunarungu sulit menginterpretasikan gerak bicara orang lain.

Kehidupan anak tunarungu akan masuk ke dalam lingkungan orang mendengar. Namun keadaan yang dialami anak tunarungu menyebabkan anak memerlukan perhatian khusus. Untuk mencapai tujuan tersebut peran orang tua dalam upaya meningkatkan keterampilan berbicara anak tunarungu sangat dibutuhkan. Alasan mengapa orang tua dikatakan sangat berperan dalam perkembangan berbicara anak adalah imitasi. Hakikatnya manusia belajar dengan melihat, mendengar dan kemudian mengimitasi. Dengan melihat manusia tahu, dengan mendengar manusia mengerti, dengan mengimitasi dan terlibat maka manusia akan memahami.

Orang yang pertama dan selalu berada disekitar anak adalah orang tua. Orang pertama yang dipercaya oleh anak adalah orang tua. Orang pertama yang ingin diimitasi oleh anak adalah orang tua. Orang pertama yang ingin dibuat bangga oleh anak adalah orang tua. Oleh sebab itu orang tua yang hebat akan mendorong anak untuk bisa menjadi seperti mereka bahkan melampaui mereka. Seperti halnya keterampilan berbicara anak tunarungu yang dikuasai dengan cara imitasi, peniruan terjadi apabila ada motivasi dari anak, dan motivasi muncul apabila ada interaksi antara anak dan orang tua. Itulah kenapa orang tua harus dapat membimbing anak mereka dengan sering mengadakan komunikasi guna merangsang motivasi anak untuk berbicara sebagai imbal balik umpan yang diberikan oleh orang tua. Hal tersebut dapat memberikan pengaruh terhadap keterampilan berbicara anak, secara konsisten orang tua melakukan percakapan dirumah bersama dengan anak, sehingga keterampilan berbicara anak akan terasah.

Sunardi dan Sunaryo (2007:193) menyatakan, MacDonald dan Gillete mencatat bahwa keterlambatan perkembangan bahasa dan bicara anak tunarungu cenderung disebabkan ketidakmampuan orangtua dan orangorang lain yang signifikan dengan anak tunarungu untuk berfungsi sebagai partner komunikasi yang baik. Itulah pengaruh orang tua terhadap anak, serta alasan mengapa orang tua sangat perlu untuk membimbing anak mereka menghadapi keterbatasan yang dimiliki, membimbing anak menemukan jalan yang sesuai untuk mencapai apa yang seharusnya bisa dicapai oleh anak. Oleh sebab itu perlu adanya bimbingan dari orang tua untuk membantu dan mengarahkan anak mereka dalam tujuan membantu penguasaan keterampilan berbicara anak. Bantuan tersebut diwujudkan dalam bentuk pemberian program bimbingan orang tua dengan materi komponen-komponen dalam keterampilan berbicara meliputi fonologi, kosakata, struktur dan kecepatan kelancaran umum.

Adanya para siswa yang berkebutuhan khusus di sekolah berimplikasi pada perubahan orientasi manajemen kelas. Pembelajaran di kelas yang mana kelas tersebut terdapat anak berkebutuhan khusus menuntut perubahan dan penyesuaian-penyesuaian. Guru kelas tidak lagi berorientasi klasikal tetapi dihadapkan pada keberagaman kebutuhan siswa. Oleh karena itu, pengelolaan kelas di sekolah menjadi hal yang sangat penting dalam tataran implementasi pendidikan. 
Pembelajaran yang bermakna bukan saja hanya mengajar dan menyampaikan informasi/pesan tetapi juga meliputi perkembangan pribadi siswa, interaksi sosial, serta penanaman sikap dan nilai pada diri siswa. Proses belajar yang bermakna akan terwujud dalam kondisi, suasana kelas yang kondusif, efektif, kreatif, produktif dan menyenangkan. Selain itu terbina hubungan interpersonal yang sehat dan mendorong munculnya perubahan perilaku belajar siswa yang diharapkan.Untuk mencapai suasana kelas tersebut maka diperlukan pengelolaan yang dilakukan guru di dalam kelas.

Sehubungan dengan pengelolaan kelas, Winataputra (1998:4) menggambarkan tentang hakekat pengelolaan kelas itu antara lain:

1. Menciptakan iklim kelas yang efektif dan produktif

2. Menciptakan hubungan interpersonal yang sehat

3. Mendorong munculnya tingkah laku yang diharapkan

4. Memberikan kebebasan siswa yang mendisiplinkan siswa.

Dengan demikian pengelolaan kelas yang efektif adalah serangkaian kegiatan yang dilaksanakan guru untuk menciptakan, memelihara dan mengembangkan kondisi kelas yang memungkinkan terjadi proses pembelajaran yang efektif dan efisien. Menurut (Weber:1997), pengelolaan kelas banyak dimaknai dengan berbagai sudut pandang. Pandangan yang menyatakan bahwa pengelolaan kelas adalah proses untuk mengontrol tingkah laku siswa. Artinya bahwa pengelolaan kelas adalah seperangkat kelas aktivitas guru untuk menciptakan dan mempertahankan aturan di dalam kelas serta ketertiban dan suasana serta atmosfir kelas melalui pendekatan disiplin kelas. Pandangan ini lebih bersifat otoriter dan sudah banyak ditinggalkan karena dianggap tidak manusiawi. Selain itu Hughes (2001:45) juga yang menganggap bahwa pengelolaan kelas adalah proses ke arah perubahan tingkah laku. Pandangan ini banyak diilhami oleh pendekatan behavior modification.

Seperti dijelaskan oleh Wragg (1996) bahwa pengelolaan kelas adalah segala sesuatu yang dilakukan guru agar anak-anak berpartisipasi aktif dalam kegiatan belajar mengajar bagaimanapun cara dan bentuknya. Berdasarkan analisis uraian teori-teori yang dikemukakan di atas dapat disintesiskan bahwa pengelolaan kelas adalah serangkaian aktivitas dan kegiatan yang dilakukan guru dalam kegiatan pembelajaran mulai dari perencanaan proses pembelajaran dalam metode, strategi dan pendekatan serta evaluasi pembelajaran sehingga tercipta kelas yang kondusif, aktif, kreatif, kooperatif dan menyenangkan melalui penciptaan lingkungan kelas yang kondusif, iklim dan suasana psiko sosial dan emosi yang positif, serta penciptaan sistem sosial yang memungkinkan anak dapat berkembang sesuai dengan kebutuhannya.

\section{SIMPULAN DAN SARAN}

Hasil analisis data di atas, maka dapat disimpulkan bahwa pengelolaan kelas terhadap siswa tuna rungu-wicara dapat melalui strategi pendekatan dan teknik tepukan dengan pengelolaan kelas yang menggambarkan tentang hakekat pengelolaan kelas itu antara lain:

1. Menciptakan iklim kelas yang efektif dan produktif

2. Menciptakan hubungan interpersonal yang sehat

3. Mendorong munculnya tingkah laku yang diharapkan

4. Memberikan kebebasan siswa yang mendisiplinkan siswa.

Penelitian ini menemukan bahwa pengelolaan kelas yang efektif adalah serangkaian kegiatan yang dilaksanakan guru untuk menciptakan, memelihara dan 
mengembangkan kondisi kelas yang memungkinkan terjadi proses pembelajaran yang efektif dan efisien. Penelitian ini merekomendasikan kepada peneliti lain untuk dapat memperluas penelitian ini sehingga mempunyai gambaran yang lebih komprehensif dengan metode penelitian yang lain ataupun dengan instrumen lain. Instrumen dengan menggunakan data kuantitatif berupa respon ataupun hasil perkembangan anak dengan tuna rungu-wicara dengan pengelolaan pembelajaran yang dilakukan dapat memberikan data yang valid tentang keegelolaan belajar yang dilakukan guru.

Saran untuk praktisi pendidikan, bahwa pendidikan untuk anak dengan kebutuhan khusus perlu menyesuaikan prinsip-prinsip pembelajaran untuk anak dengan kebutuhan khusus agar dapat dicapai perkembangan anak usia dini dengan optimal.

\section{AKNOWLEDGMENT}

Peneleitian ini di dukung oleh UIN Sunan Ampel Surabaya. RA Mamba'ul Hisan Surabaya

\section{DAFTAR RUJUKAN}

Effendi, Mohammad. 2006. Pengantar Psikopedagogik Anak Berkelainan. Jakarta : Bumi Aksara.

Sadjah, Edja dan Sukarja, Dardjo. Tanpa Tahun. Bina Bicara, Persepsi Bunyi dan Irama. Bandung : Depdikbud

Sunardi dan Sunaryo. 2007. Intervensi Dini Anak Berkebutuhan Khusus. Jakarta : Depdiknas.

Somantri, Sutjihati. 2006. Psikologi Anak Luar Biasa. Bandung : Refika Aditama.

Republika On Line:http://www.republ ika.co.id

\section{AUTHOR}

Aprilia Rahmawati, merupakan Mahasiswa S1 Program Studi Pendidikan Islam Anak Usia Dini UIN Sunan Ampel Surabaya

Juhaeni, Dosen PGMI UIN Sunan Ampel Surabaya dan menjadi penulis dibeberapa jurnal di indonesia

Siti Aisah, merupakan Guru Kelompak A1 RA Mamba'ul hisan Surabaya Ayu Kinasih, merupakan Mahasiswa S1 Program Studi Pendidikan Islam Anak Usia Dini UIN Sunan Ampel Surabaya

Nur Shibyany, merupakan Mahasiswa S1 Program Studi Pendidikan Islam Anak Usia

Dini UIN Sunan Ampel Surabaya 